PACS: $98.62 . \mathrm{Sb}$

\title{
FIXED POINTS FEATURES IN N-POINT GRAVITATIONAL LENSES
}

\author{
DVolodymyr Shablenko \\ V.N. Karazin Kharkiv National University \\ 4, Svobody sq., 61022, Kharkiv, Ukraine \\ E-mail:Shablenkov@gmail.com \\ Received 15 July 2019; revised August 5, 2019; accepted August 30, 2019
}

\begin{abstract}
A set of fixed points in N-point gravitational lenses is studied in the paper. We use complex form of lens mapping to study fixed points. There are some merits of using a complex form over coordinate. In coordinate form gravitational lens is described by a system of two equations and in complex form is described by one equation. We transform complex equation of N-point gravitational lens into polynomial equation. It is convenient to study polynomial equation. Lens mapping presented as a linear combination of two mappings: complex analytical and identity. Analytical mapping is specified by deflection function. Fixed points are roots of deflection function. We show, that all fixed points of lens mapping appertain to the minimal convex polygon. Vertices of the polygon are points into which dimensionless point masses are. Method of construction of fixed points in N-point gravitational lens is shown. There are no fixed points in 1-point gravitational lens. We study properties of fixed points and their relation to the center of mass of the system. We obtained dependence of distribution of fixed points on center of mass. We analyzed different possibilities of distribution in N-point gravitational lens. Some cases, when fixed points merge with the center of mass are shown. We show a linear dependence of fixed point on center of mass in 2-point gravitational lens and we have built a model of this dependence. We obtained dependence of fixed point to center of mass in 3-point lens in case when masses form a triangle or line. In case of triangle, there are examples when fixed points merges. We study conditions, when there are no one-valued dependence of distribution of fixed points in case of 3-points gravitational lens and more complicated lens.
\end{abstract}

KEY WORDS: gravitational lensing, fixed points, deflection function, lens mapping

Effect of gravitational lensing has evolved from a method of verification of general relativity to separate field over the years. Using gravitational lenses, stars, stars system and even planets can be found.

Often numerical methods were used to analyze gravitational lenses and analytically were described only special symmetrical systems $[1,2]$. But these days, gravitational lenses are studied using analytical methods, particularly using methods of algebraic geometry [3-6]. With algebraic geometry methods we were able to study an Einstein ring - an important object in gravitational lensing - and prove that it is the only extended image in N-point gravitational lenses [4].

Circle source in N-point gravitational lens of any configurations was built using methods of algebraic geometry [7].

It is important to study fixed points in the theory of gravitational lenses [8]. Fixed points were researched before [9]. In paper [9] were shown examples of fixed points.

This paper proposes methods to study the distribution of fixed points. We show the distribution of fixed points and study its properties in N-point gravitational lenses.

The goal of this work is studying of a set of fixed points in N-point gravitational lenses using analytical methods, finding features of fixed points.

FORMULATION OF THE PROBLEM

N-point gravitational lens can be described by following equation

$$
\vec{y}=\vec{x}-\sum_{n} m_{n} \frac{\vec{x}-\vec{l}_{n}}{\left|\vec{x}-\vec{l}_{n}\right|^{2}},
$$

where $m_{n}$ - are dimensionless masses whose position in the plane of the lens is determined by normalized radius-vectors $\vec{l}_{n}, \sum_{n} m_{n}=1$

Equation (1) specifies single-valued mapping from linear vector space $R_{y}^{2}$ (source plane) into linear vector space $R_{x}^{2}$ (image plane):

$$
L:\left(R_{x}^{2} \backslash \Lambda\right) \rightarrow R_{y}^{2},
$$

where $\Lambda=\left\{l_{i} \mid i=1,2, \ldots, N\right\}$ - is a set of radius-vectors $\vec{l}_{i}$. 
Unification of source plane and image plane is referred as picture plane.

Mapping (2) can be described by system of equations:

$$
\left\{\begin{array}{l}
y_{1}=x_{1}-\sum_{n=1}^{N} m_{n} \frac{x_{1}-a_{n}}{\left(x_{1}-a_{n}\right)^{2}+\left(x_{2}-b_{n}\right)^{2}} \\
y_{2}=x_{2}-\sum_{n=1}^{N} m_{n} \frac{x_{2}-b_{n}}{\left(x_{1}-a_{n}\right)^{2}+\left(x_{2}-b_{n}\right)^{2}}
\end{array}\right.
$$

where $\left(a_{n}, b_{n}\right)$ are coordinates of point $C_{n}$ in plane $R_{x}^{2}$.

\section{LENS MAPPING COMPLEXIFICATION}

It is more convenient to use complex form of lens mapping in order to find fixed points [8]. We introduce new complex variables:

$$
\operatorname{Re} z=x_{1}, \operatorname{Im} z=x_{2}, \operatorname{Re} \zeta=y_{1}, \operatorname{Im} \zeta=y_{2} .
$$

New variables are related to old ones as:

$$
\left\{\begin{array} { l } 
{ x _ { 1 } = \frac { z + \overline { z } } { 2 } } \\
{ x _ { 2 } = \frac { z - \overline { z } } { 2 } }
\end{array} \text { and } \left\{\begin{array}{l}
y_{1}=\frac{\zeta+\bar{\zeta}}{2} \\
y_{2}=\frac{\zeta-\bar{\zeta}}{2}
\end{array}\right.\right. \text {, }
$$

Using new variables, mapping can be described by following equation:

$$
\zeta=z-\sum_{n=1}^{N} m_{n} \frac{1}{\bar{z}-\overline{A_{n}}},
$$

where $\sum_{n=1}^{N} m_{n}=1$ and $A_{n}=a_{n}+i b_{n}$ are lenses coordinates; $n=1,2, \ldots, N$.

Deflection function was introduced in [8]:

$$
\omega=\sum_{n=1}^{N} m_{n} \frac{1}{\bar{z}-\overline{A_{n}}}
$$

And function is complex conjugated to $\omega$ and defined:

$$
w=\sum_{n=1}^{N} m_{n} \frac{1}{z-A_{n}}
$$

It is convenient to use $w$ and $\omega$ to find fixed points of lens mapping, except that it is more convenient to use $w$.

We use properties of complex mapping that were studied in [8]. It is known [8,11] that deflection function $w=w(z)$ is analytical.

There are some theorems.

Theorem 1. Deflection function $w$ can be represented

a)

$$
w=\frac{Q^{\prime}(z)}{Q(z)},
$$

where $Q(z)=\prod_{n=1}^{N}\left(z-A_{n}\right)^{m_{n}}$

b)

$$
w=\frac{1}{\operatorname{deg} P(z)} \cdot \frac{P^{\prime}(z)}{P(z)},
$$

where $P(z)$ - is polynomial; 
Theorem 2. (About number). Let $n_{0}$ be a number of fixed points of mapping $L:\left(\mathbb{C}_{X} \backslash \Lambda\right) \rightarrow \mathbb{C}_{Y}$, therefore $n_{0}: 1 \leq n_{0} \leq N-1$.

Theorem 3. (About distribution). Fixed points of mapping $L$ belong to the convex polygon that consists of point masses.

Consider N-point gravitational lens.

\section{N-POINT LENSES}

We change masses of point lenses and their positions are set to constant. Hence, fixed points depend on $\mathrm{N}$ parameters (masses of lenses). Besides, point masses are bounded by masses normalization equation. There is a necessary condition to find the parameters of fixed points distribution parameters. We need the same number of free parameters as number of equations. Therefore, we need either to decrease the number of parameters or to increase the number of equations.

To decrease number of equations we can express masses in terms of masses center of point masses system. It is convenient to describe 2- or 3- points gravitational lenses accordingly to this method. But we need to introduce new additional conditions to describe more complicated systems.

Deflection function of 1-point lens is:

$$
w=\sum_{n=1}^{N} m_{n} \frac{1}{z-A_{n}}=\frac{m_{1}}{z-A_{1}},
$$

where $m_{1}=1, A_{1}=0$. There are no fixed points in 1-point gravitational lens.

Deflection function of 2-points lens is:

$$
w=\sum_{n=1}^{N} \frac{m_{n}}{z-A_{n}}=\frac{m_{1}}{z-A_{1}}+\frac{m_{2}}{z-A_{2}}
$$

where $m_{1}+m_{2}=1$.

Fixed point is given by:

$$
z_{s t}=A_{1} m_{2}+A_{2} m_{1}
$$

To find fixed point, we can parameterize point masses in such way $m_{1}=s, m_{2}=1-s, s \in[0,1]$, then

$$
z_{s t}=A_{1}+\left(A_{2}-A_{1}\right) s
$$

We can also use equation for center of mass: $z_{c}=m_{1} A_{1}+m_{2} A_{2}$.

If we express fixed point using the center of mass, we obtain:

$$
z_{s t}=A_{1}+A_{2}-z_{z} .
$$

Thus, we obtained equation for fixed point in 2-point gravitational lens. The equation is linear. Masses are located symmetrically in relation to the geometrical center of the system. Fixed point and center of mass can coincide only when there are 2 identical masses. In this case, fixed point and center of masses are located in the geometrical center of the line segment that is connecting 2 masses.

Deflection function of 3-point gravitational lens is:

$$
w=\frac{m_{1}}{z-A_{1}}+\frac{m_{2}}{z-A_{2}}+\frac{m_{3}}{z-A_{3}}
$$

We have an equation for fixed points:

$$
\begin{gathered}
z^{2}+A_{2} A_{3} m_{1}+A_{1} A_{3} m_{2}+A_{1} A_{2} m_{3}- \\
-\left(A_{2} m_{1}+A_{3} m_{1}+A_{1} m_{2}+A_{3} m_{2}+A_{1} m_{3}+A_{2} m_{3}\right) z=0
\end{gathered}
$$


We can set different parameterization for point masses in this case. There are some different mass parameterizations in 3-point gravitational lenses on (fig.1-4). There are gravitational lenses with masses that form triangle on (fig.1-2) and line in (fig. 3-4).

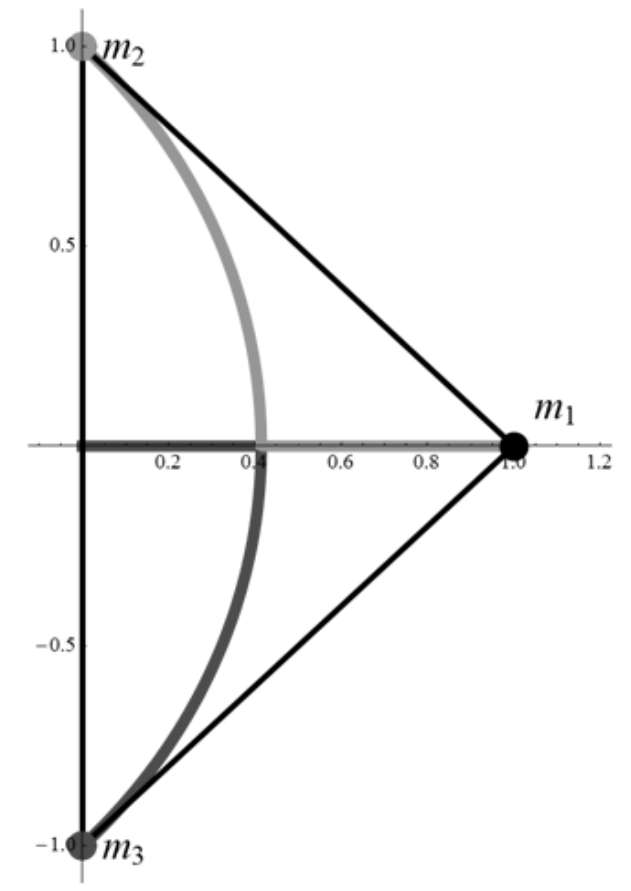

Fig. 1. 3-point lens with

$m_{1}=1-s, m_{2}=s / 2, m_{3}=s / 2, A_{1}=1, A_{2}=i, A_{3}=-i$

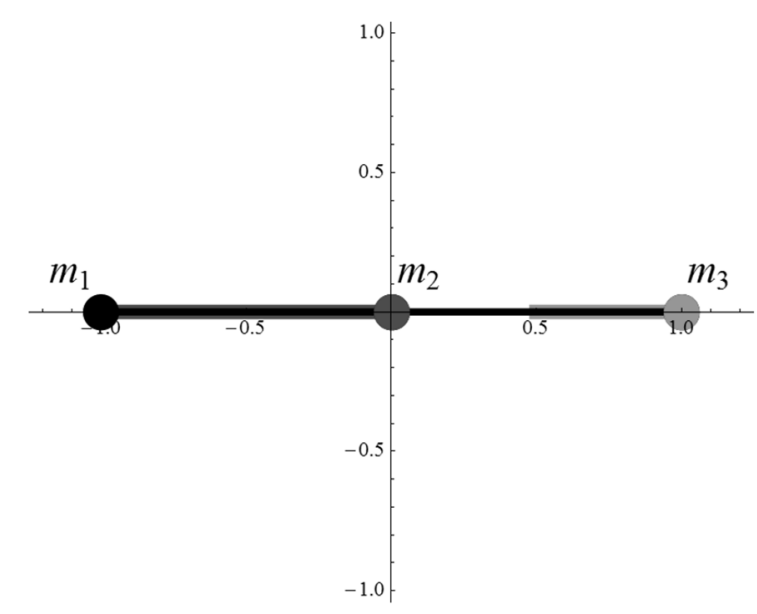

Fig. 3. 3-point lens with

$$
m_{1}=1-s, m_{2}=s / 2, m_{3}=s / 2, A_{1}=-1, A_{2}=0, A_{3}=1
$$

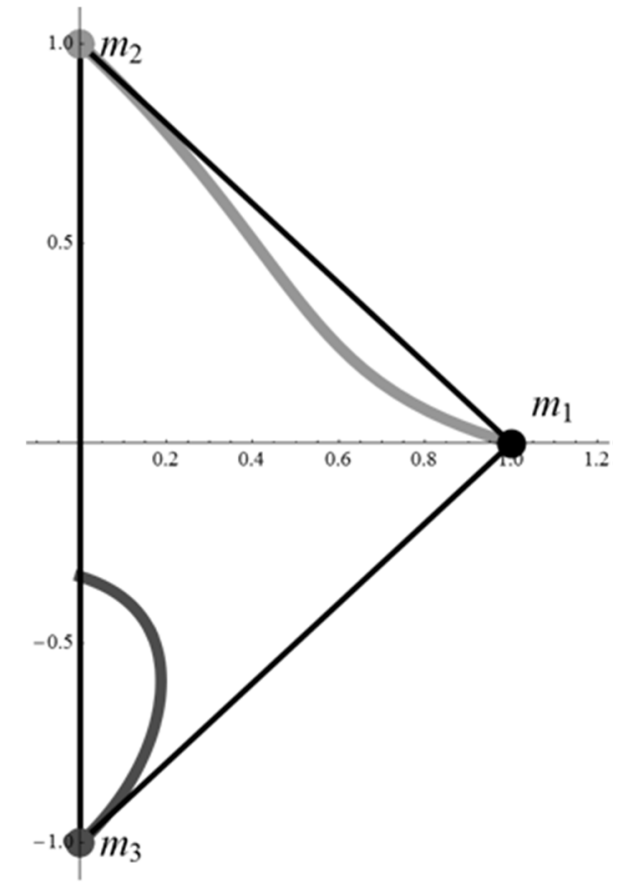

Fig. 2. 3-point lens with

$$
m_{1}=1-s, m_{2}=2 s / 3, m_{3}=s / 3, A_{1}=1, A_{2}=i, A_{3}=-i
$$

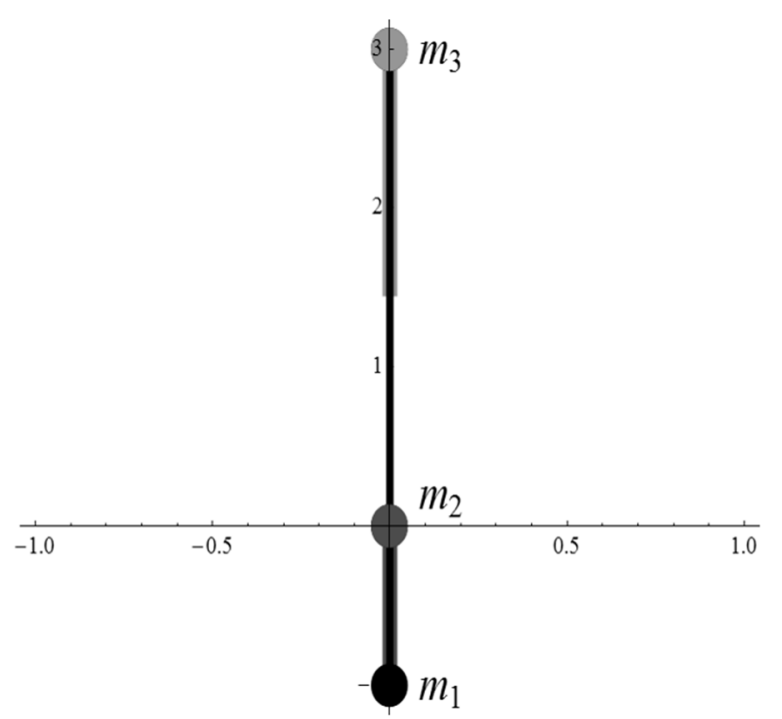

Fig. 4. 3-point lens with $m_{1}=1-s, m_{2}=s / 2, m_{3}=s / 2, A_{1}=-i, A_{2}=0, A_{3}=3 i$

We can describe a fixed point using the center of mass:

$$
z_{c}=x_{c}+i y_{c}=m_{1} A_{1}+m_{2} A_{2}+m_{3} A_{3},
$$

If point masses form a triangle, we can obtain one-valued dependence of fixed points on center of mass. There is only 1 pair of fixed points per each center of mass. We put point masses in positions with $A_{1}=a_{1} i, A_{2}=a_{2}, A_{3}=a_{3}$. We obtain equation on fixed points: 


$$
\begin{aligned}
& z_{1,2}=\frac{1}{2 A_{1}}\left[A_{1}^{2}+A_{1} A_{2}+A_{1} A_{3}-A_{1} x_{c}-A_{1} y_{c} \pm\right. \\
& \left. \pm \sqrt{\left(A_{1}^{2}+A_{1} A_{2}+A_{1} A_{3}-A_{1} x_{c}-A_{1} y_{c}\right)^{2}+4 A_{1}\left(-A_{1}^{2}\left(A_{2}+A_{3}-x_{c}\right)+y_{c}\left(A_{1} A_{2}+A_{1} A_{3}-A_{2} A_{3}\right)\right.}\right]
\end{aligned}
$$

Using technical computing system, Wolfram Mathematica, we built mathematical model that shows the distribution of fixed points. A parameter in the model is the center of mass. To build a more general picture, we set simultaneously horizontal line of the possible center of mass. Thus, we can see 1 line of the center of mass and 2 curves of fixed points that match centers of masses.

Using our model, we obtain when 3-point lens forms equilateral triangle we have 2 fixed points that merge (Fig.5-6). In case when the center of mass of the triangle is geometrical center of the triangle, fixed points are located in 1 point. Situation, when masses are almost equal is shown on (Fig. 5) and equal masses are shown on (Fig.6).

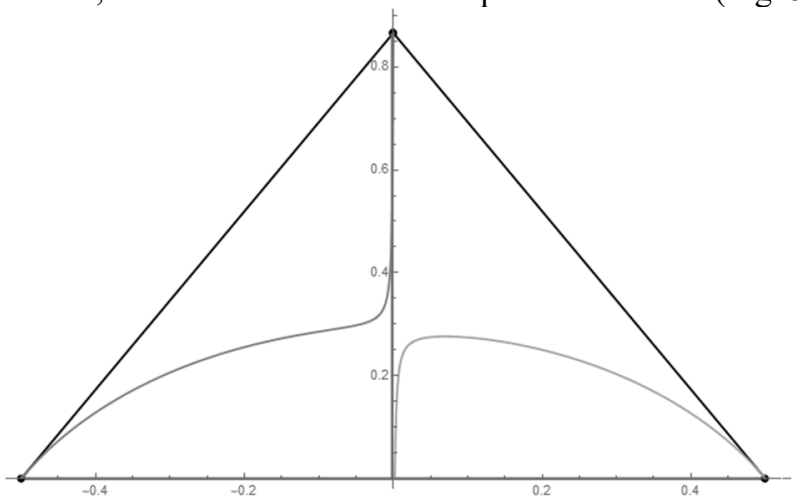

Fig. 5. Equilateral triangle with center of mass near to geometrical center

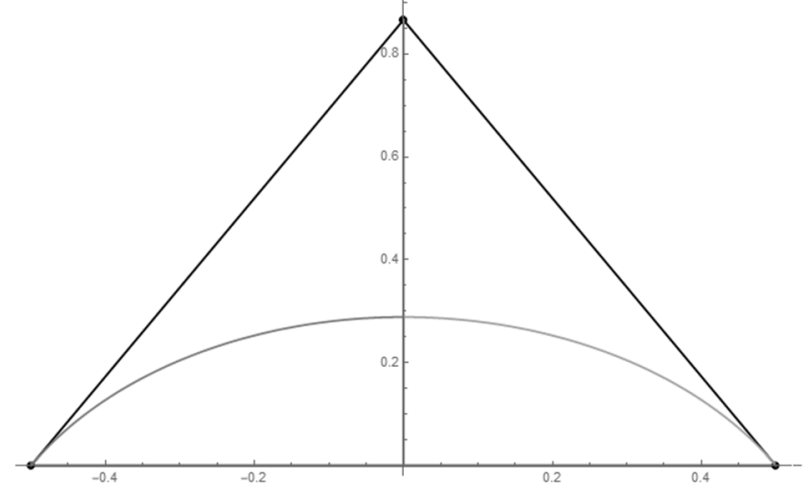

Fig. 6. Equilateral triangle with center of mass in geometrical center

Consider scalene triangle. There was an assumption in [8] that fixed points can merge only in case when point masses form regular polygon. But in case of scalene triangle we have found cases of merging of fixed points. There is a configuration of 3-point gravitational lens when in a forms scalene triangle with the merging of fixed points on (Fig.7-8). A mass configuration with two separate fixed points is shown in (Fig. 7) and configuration with merged fixed points is shown on (Fig. 8).

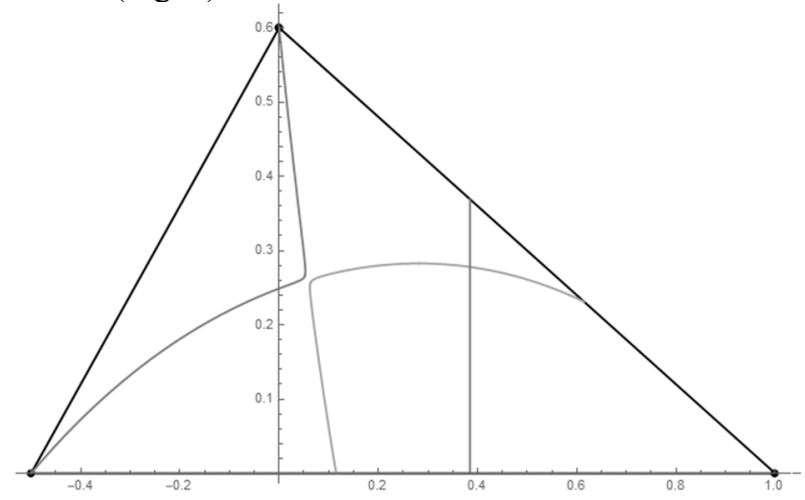

Fig. 7. Scalene triangle with 2 separate fixed points

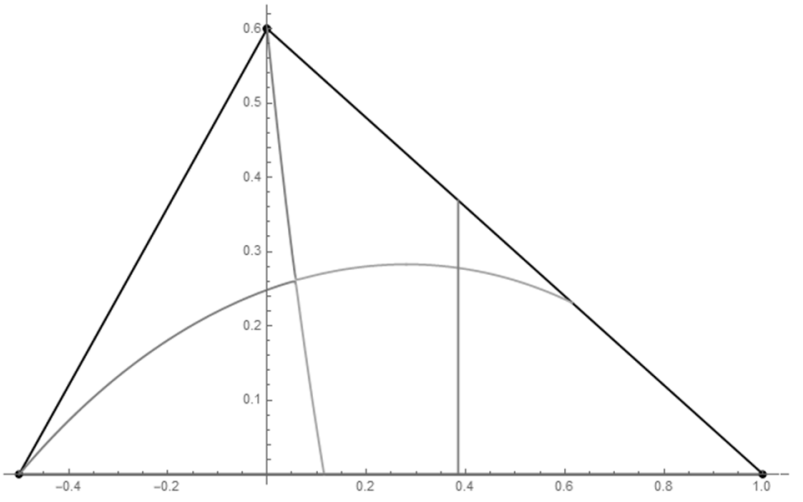

Fig. 8. Scalene triangle with merged fixed points

Fixed points in 3-point gravitational lens can coincide only in case either equilateral triangle or when the system is reduced to 2-point gravitational lens.

If point masses are located along line, number of equations, that are used to describe masses, decreases by 1 . In this case we need to introduce 1 additional parameter. The same center of mass can describe different distribution of masses. Considering this feature, we can obtain different fixed points for the same center of mass. We introduce additional parameter, for example, $1-m_{2}=\alpha$. Thus, changing $\alpha$, we can obtain different combinations of masses for the same center of mass. And besides, this parameter limits the position of center of mass. For example, when we have 3-point lens with masses in $(-0.5,0),(0,0),(0.7,0)$, position of center of mass is limited by $x_{c} \in(-0.5 \alpha ; 0.7 \alpha)$.

There is a distribution of fixed points with different $\alpha$ on (Fig. 9). Lenses are located in $(-0.5 ; 0),(0,0)$ and $(0.7 ; 0)$, centers of mass are in $(0.1 ; 0)$. On left image $a=0.26$, on right image $a=0.92$. 
Deflection function of 4-point gravitational lens:

$$
w=\frac{m_{1}}{z-A_{1}}+\frac{m_{2}}{z-A_{2}}+\frac{m_{3}}{z-A_{3}}+\frac{m_{4}}{z-A_{4}}
$$

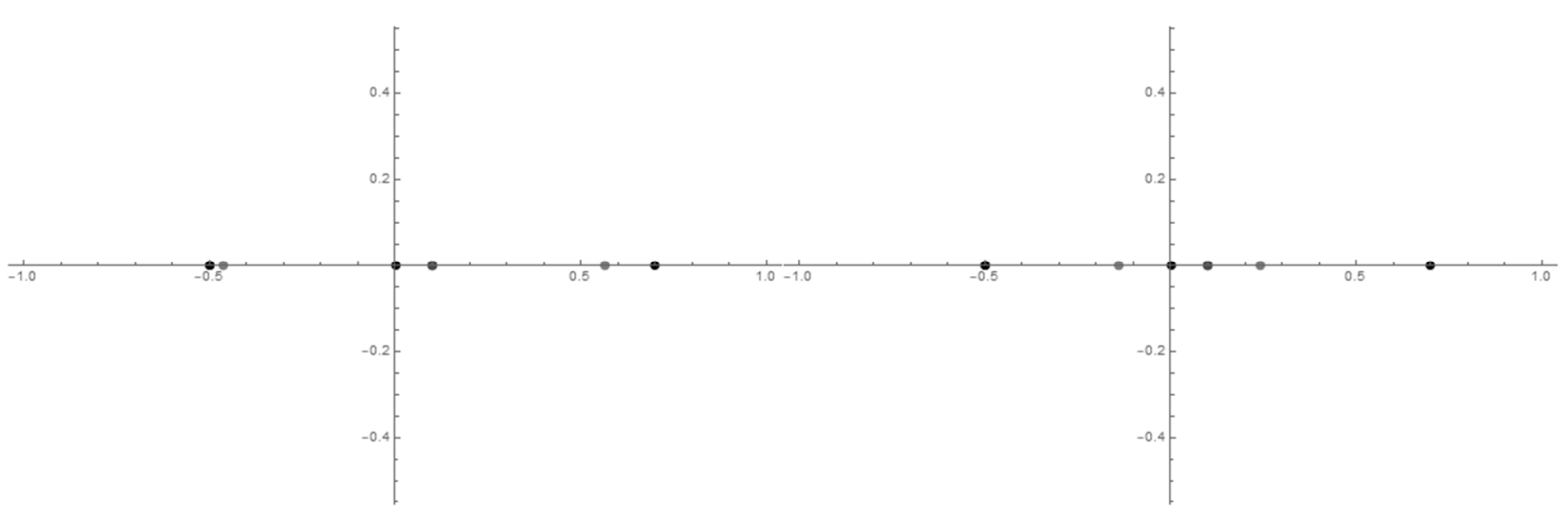

Fig. 9. 3-point lens with masses on a line with different parameter $\alpha$

Using parameterization, different distributions of fixed points can be obtained. Examples of different parametrization in 4-point gravitational lenses are shown in (Fig.10-12). Triangle consists of 4 masses is shown on (Fig. 10), the square is shown in (Fig. 11) and triangle with 1 internal mass is shown in (Fig. 12).

We need to introduce more additional parameters to study gravitational lenses with 3 or more-point masses. Thus, it is more complicated to apply this method and it is only convenient to study 2- and 3- point gravitational lenses.

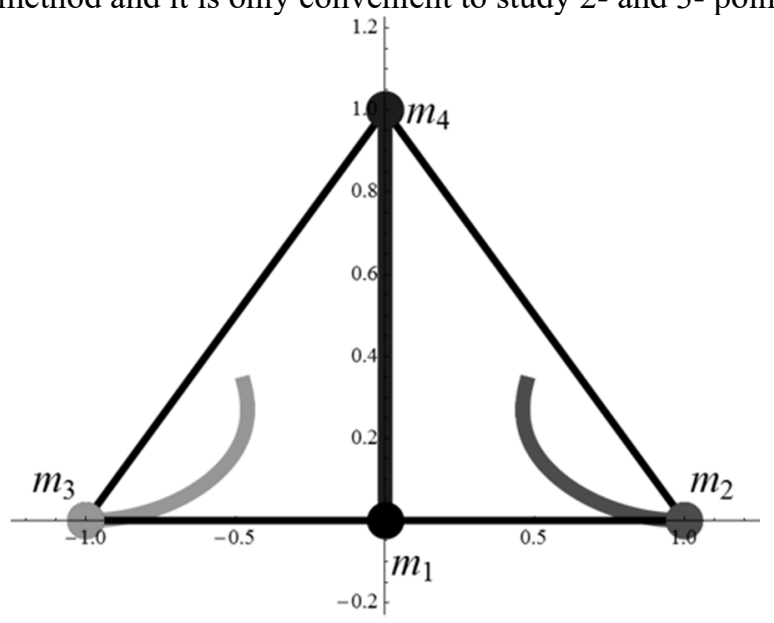

Fig. 10. 4-point lens with $m_{1}=1-s, m_{2}=s / 3, m_{3}=s / 3, m_{4}=s / 3 A_{1}=0, A_{2}=1, A_{3}=-1, A_{4}=i$

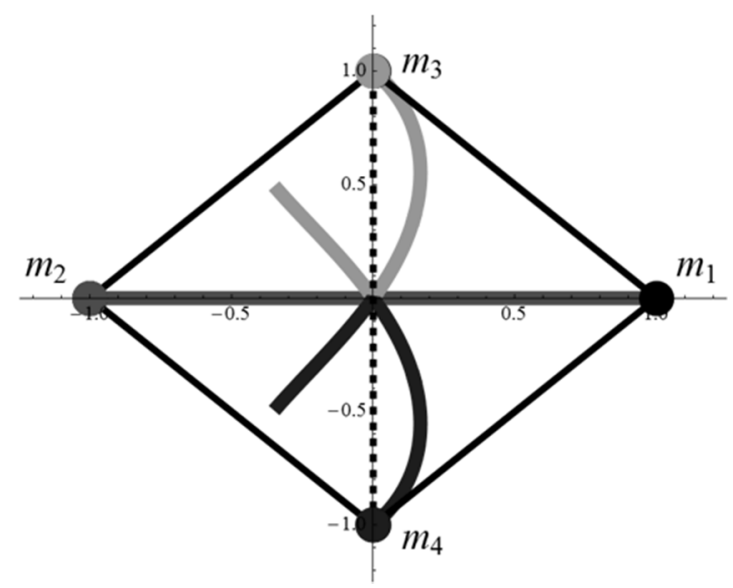

Fig. 11. 4-point lens with $m_{1}=1-s, m_{2}=s / 3, m_{3}=s / 3, m_{4}=s / 3 A_{1}=1, A_{2}=-1, A_{3}=i, A_{4}=-i$ 


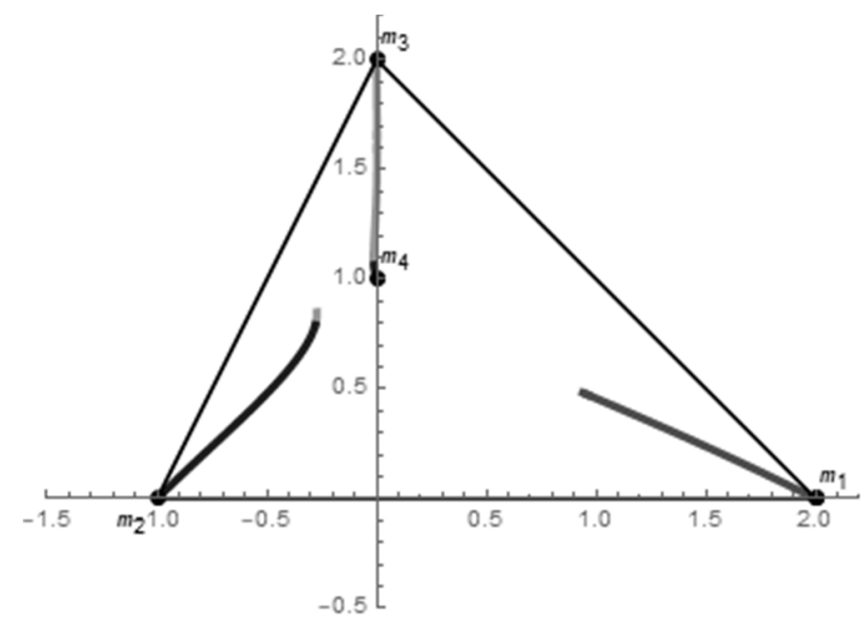

Fig. 12. 4-point lens with $m_{1}=1-s, m_{2}=s / 3, m_{3}=s / 3, m_{4}=s / 3 A_{1}=2, A_{2}=-1, A_{3}=2 i, A_{4}=i$

\section{CONCLUSIONS}

Method of obtaining of fixed points distribution in N-point gravitational lenses is shown in this study paper. We show a linear dependence of the fixed point location on center of mass in 2-point gravitational lens. Distribution of fixed points in 3-point gravitational lens is obtained using the center of mass of the system. We show that fixed points in 3-point gravitational lenses can merge. There are examples of distribution of fixed points in 4-point gravitational lens.

Volodymyr Shablenko ${ }^{(1)}$ https://orcid.org/0000-0003-4162-4154

\section{ORCID IDs}

\section{REFERENCES}

[1] E.Y. Bannikova and A.T. Kotvytskiy, MNRAS 445(4):4435-4442, (2014), DOI: 10.1093/mnras/stu2068.

[2] A.T. Kotvytskiy, TMP 184(1):160-174, (2015), DOI: 10.1007/s11232-015-0315-x.

[3] A.T. Kotvytskiy, S.D. Bronza and S.R. Vovk, Journal of Kharkov National University V.N. Karazin. Series: Physics, 24, 55-59 (2016)

[4] A.T. Kotvytskiy, S.D. Bronza, K.Yu. Nerushenko and V.Yu. Shablenko, in: Збірник наукових пращь VI-ї Міжрегіональноі науково-практичної конференції «Астрономія і сьогодення»: Collection of scientific researches of VI interregional scientificpractical conference "Astronomy and Present" (Vinnytsia, 2017). pp.198-213 (in Ukrainian)

[5] A.T. Kotvytskiy and S.D. Bronza, Odessa Astronomical Publications, 29, 31-33, (2016).

[6] S.D. Bronza and A.T. Kotvytskiy, Journal of Kharkiv National University V.N. Karazin, Series: Physics, 26, 6-32 (2017).

[7] S.D. Bronza, Ju.V. Svyrydova and L.A. Kotvytska, Odessa Astronomical Publications, 31, 6-10, (2018), DOI: 10.18524/18104215.2018.31.144434.

[8] A.T. Kotvytskiy, V.Yu. Shablenko and E.S. Bronza, Odessa Astronomical Publications, 31, 24-28, (2018), DOI: 10.18524/18104215.2018.31.144558.

[9] A.O. Petters and F.J. Wicklin, Journal of Mathematical Physics 39, 1011 (1998), DOI: 10.1063/1.532367.

[10] P. Schneider, J. Ehlers, E.E. Falco, Gravitational Lenses. (Springer-Verlag, Berlin Heidelberg, 1997), pp. 266.

[11] H.J.Witt, A\&A, 236(2), 311-322, (1990).

\section{ОСОБЛИВОСТІ НЕРУХОМИХ ТОЧОК В N-ТОЧКОВИХ ГРАВІТАЦЙНИХ ЛІНЗАХ}

\section{В.Ю. Шабленко}

Харківський начіональний університет імені В.Н. Каразіна

Майдан Свободи, 4, 61022, Харків, Україна

В роботі проведене дослідження множини нерухомих точок в N-точкових гравітаційних лінзах. Для цього була використана комплексна форма лінзового відображення. Комплексна форма має перевагу над координатною: в координатний форми Nточкова гравітаційна лінза задається системою з двох рівнянь, а в комплексному вигляді досить одного рівняння. Це рівняння легко перетвориться в поліноміальне рівняння, яке зручне для дослідження. В роботі лінзове відображення представлено у вигляді лінійної комбінації двох відображень: комплексно-аналітичного і тотожного. Аналітичне відображення задає аналітична функція (функція відхилення). Нерухомими точками є корені функції відхилення. Показано, що всі нерухомі точки лінзового відображення належать мінімальному опуклому багатокутнику. Вершинами мінімального опуклого багатокутника $\epsilon$ точки, в яких знаходяться безрозмірні точкові маси. В роботі розглянутий метод побудови нерухомих точок в $\mathrm{N}$-точкових гравітаційних лінзах. Було показано, що нерухомих точок в одноточковій лінзі не існує. Досліджені властивості нерухомих точок i ïх зв'язок з центром мас системи лінз. Отримані залежності розподілу нерухомих точок від центра мас. Проаналізовані різні можливі випадки розподілу в $\mathrm{N}$-точкових гравітаційних лінзах. Показано, що у деяких випадках нерухомі точки збігаються з центром мас системи. Було отримано лінійну залежність між нерухомою точкою в двоточковій гравітаційній лінзі та центром мас та побудували модель. Отримали залежність нерухомих точок від центру мас в 3-точковій гравітаційній 
лінзі в випадку коли лінза утворює трикутник та пряму. Показали, що в випадку трикутника існують приклади, коли збігаються нерухомі точки. Досліджені умови, коли неможливо однозначно отримати залежність розподілу нерухомих точок від центру мас у випадку 3-точкової гравітаційної лінзи та у більш складних випадках.

КЛЮЧОВІ СЛОВА: гравітаційне лінзування, нерухомі точки, функція відхилення, лінзове відображення

\section{ОСОБЕННОСТИ НЕПОДВИЖНЫХ ТОЧЕК В N-ТОЧЕЧНЫХ ГРАВИТАЦИОННЫХ ЛИНЗАХ}

\section{В.Ю. Шабленко}

Харьковський национальный университет имени В.Н. Каразина

Плошадь Свободы, 4, 61022, Харьков, Украина

В работе проведено исследование множества неподвижных точек в N-точечных гравитационных линзах. Для этого была использована комплексная форма линзового отображения. Комплексный вид имеет преимущество на координатным: в координатном виде $\mathrm{N}$-точечная гравитационная линза задается системой из двух уравнений, а в комплексном виде достаточно одного уравнения. Это уравнение легко превращается в полиномиальное уравнение, которое удобно для исследования. В работе линзовое отображение представлено в виде линейной комбинации двух отображений: комплексно-аналитического и тождественного. Аналитическое отображение задает аналитическая функция (функция отклонения). Неподвижными точками являются корни функции отклонения. Показано, что все неподвижные точки линзового отображения принадлежат минимальному выпуклому многоугольнику. Вершинами минимального выпуклого многоугольника являются точки, в которых находятся безразмерные точечные массы. В работе рассматривается метод построения неподвижных точек Nточечных гравитационных линзах. Было показано, что неподвижных точек в одноточечной линзе не существует. Были исследованы свойства неподвижных точек и их связь с центром масс системы линз. Получены зависимости распределения неподвижных точек от центра масс. Проанализированы различные возможные случаи распределения в N-точечных гравитационных линзах. Показано, что в некоторых случаях неподвижные точки совпадают с центром масс системы. Была получена линейная зависимость между неподвижной точкой в двухточечной гравитационной линзе и центром масс системы и была построена модель. Мы получили зависимость неподвижных точек от центра масс в 3-точечной гравитационной линзе в случае, когда линза образовывает треугольник и прямую. Показали, что в случае треугольника существуют примеры, когда неподвижные точки совпадают. Исследованы условия, когда невозможно однозначно получить зависимость распределения неподвижных точек от центра масс системы в случае 3-точечной гравитационной линзы и в более сложных случаях.

КЛЮЧЕВЫЕ СЛОВА: гравитационное линзирование, неподвижные точки, функция отклонения, линзовое отображение 